\title{
Tourism as a Means of Resolving the Armed Conflicts in the Middle East
}

\author{
Akmal Ramadan Amin \\ Lecturer at the Faculty \\ of \\ Tourism and Hotels Management \\ Alminya University, Egypt
}

\section{Introduction:}

Speaking about peace and Armed Conflicts in the Middle East calls us for eulogizing and standing to mourn the martyr Egyptian president "Sadat" who took the initiative in bringing about a practical peace to the Middle East between Egypt and Israel. It was a true peace coming from the bottom of the heart, mind, and conscience. Satad brought about October victory and the first peace initiative between the Arabs and Israel. Sadat has precedence over anyone in stopping bloodshed and respecting human rights. In my genuine opinion, his Knesset address is equal to an international convention for protecting human rights. Mercy be upon Sadat without whom I will not be able to be among you here in this great scholarly conference. I may not be an exaggerator if I said that my essential motive of choosing this research is my personal and sentimental state of being impressed by the personality and charisma of the departed martyr Sadat (President Sadist's Address To The Knesset., 1977)

The humble beginnings of peace and tourism can be traced back to early history when envoys were often sent to negotiate peace treaties, develop trade, or spread religious beliefs in other parts of the world. However, it was probably until 1986 when the International Institute of Peace through Tourism (IIPT) was established that the relationship between peace and tourism gained formal recognition globally. Founded in the United Nations International Year of Peace, the goal of IIPT was to leverage on the tourism industry to bring peace to a world plagued by terrorist activities, political strains, environmental degrading, and economic disparities. (Xiangru Tang, Clara 2005).

Thereafter, numerous peace and tourism movements, including the Global Peace Parks Project, Global Summit on Peace through Tourism, and IIPT regional and global conferences, have been organized at national, regional, and international levels, demonstrating the travel industry's commitment to building a culture of peace universally (IIPT Global Conferences 2004). 
Today, the close relationship between peace and lownism reinforced again due to the series of political socio-cultural econm and environmental instabilities in the last four years. As the travel ind gradually recovers from the 9-11 attack on America in 2001. Bali torms. in 2002., SARS outbreak in 2003, Asia Tsunami disaster in 2004 and the

There is no doubt that the world now wants to achieve a permanen peace based on the understanding among peoples and the dirert acquaintance among the citizens of different countries. In fact these two things became inevitable after possessing modern deadly nuclear weapons that threatened the existence of the humanity itself with all of its achievement. Thus tourism has a greater importance because it will not stand on its feet or prosper but under peace, security and stablity. It is also based on the direct communication among peoples, deepening information, interaction of civilizations and exchanging knowledge and accordingly it will lead to the spreading of an international understanding and forgiveness in a way that will serve the peace issue around the world (Mandela, Nelson 2000).

Over the years tourism was considered as a criterion for the development of the international relations regarding the economic. political, and social aspects where the effective contributions tend to achieve world peace. Add to that, the UN with its development program and the specialized UN agencies as the Labor organization, the UNESCO and also all governmental, non-governmental, regional and international specialized unions working on tourism and now on top of it World Tourism Organization established in 1975, all these bodies and organizations tend to enhance cooperation among the countries and peoples in order to solve their political, economic, and social problems, all this will pave the way for achieving tourist cooperation among them and also organizing it on scientific and technical bases for reaching the desired world peace (Frangialli, Francesco 2003).

As a matter of fact tourism is one of the largest economic activities in the worid, it accounts for the largest international and domestic movement of people. It may even be the largest single industry in the world. It is the world's largest employer and the leading item of the trade in services. On the international level, this activity has political, economic and social ramifications (Wahab, Salah 1996,1998, 2003).

But the purpose of this paper is not to discuss the traditional economic importance of tourism; it is rather to show the role of intemational tounism in resolving the problems of armed conflict in the Middle East.

The relation between tourism and security cannot be ignored Undoubtedly, tourism is negatively affected by violence, terrorism and whatever kinds of armed conflicts. What is going on in the Middle East is a living evidence of this reality. On the other hand, my point is to show to what extent the tourist flow to the Middle East is a positive factor that could put an end to the deadly armed conflicts this universally important region has suffered for so long. Tourism could place considerable pressure on 
the international community to take the initiative 10 put an end 10 armed conflicts. Tourism can be regarded as one of the major factors that urge the governments over the world to fight all sorts of armed conflicts
(Mowforth, Martin, Munt, lan 2004).

It is also my concern to demonstrate the dynamic interaction between tourism and world peace, and the importance of lourism in achieving some considerable degree of closeness between different nations and people through enhancing the idea of the dialogue of civilizations instead of the clash of civilizations. Tourism does not only foster economic development but also supports human understanding. It gives people the opportunity to be acquainted with the cultural heritage of other nations. The tourist will be subjected to the natural as well as the cultural environment. His tourist tour includes landscapes, historic places, sites and established environments, in addition to biodiversify, collections, past and present cultural practices, knowledge and living experiences Accordingly, he will recognize how cultural heritage forms the essence of various national, regional and indigenous identities. It is also an integral part of the character of nations, and how the heritage and collective memory of each locality or community represent an irreplaceable and important basis for development, now and in the future (Voicu, loan 2004).

\section{Chapter i}

\section{The Opposite Relation between the international tourists flows and armed conflicts}

It cannot be ignored that Tourism is an important source of national income to the countries of Middle East. The tourism industry generates substantial economic benefits to host countries all over the world. The main benefits of tourism to a country are foreign exchange earnings, tax revenues, business opportunities for budding entrepreneurs, and employment for workers in the industry. According to the WTO, "Tourism is one of the top five export categories for as many as $83 \%$ of countries and is the main source of foreign exchange earnings for at least $38 \%$ of countries ., 698 million people traveled to a foreign country in 2000 . spending more US $\$ 478$ billion. International tourism receipts combined with passenger transport currently total more than US\$ 575 billion making tourism the world's number one export earner, ahead of automotive products, chemicals, petroleum and food (WTO Tourism and Poverty Alleviation, Madrid 2002).

Foreign exchange earnings from exports are used to purchase imports and augment reserves. They generate income in the host country and can stimulate consumer spending and investment in other sectors of the economy. The tourism industry provides tremendous opportunity for relatively small businesses to thrive and also a leading generator of jobs. The hotel accommodation sector alone provided around 11.3 million jobs worldwide in 1995, according to the United Nations Environmental Program (UNEP). Tourism generates jobs directly through hoteis, restaurants, nightclubs, taxis, and souvenir sales. Indirectly, jobs are generated through the supply of goods and services required by tourism- 
reiated suppliers. The WIO estimates that tourism represents $7 \%$ of jobs
worldwide (The Global Economics Game, 2000).

Any decline in tourism spending generates a magnified negative impact on total spending and employment. War, terrorism, crime, and international importance, it is an especially important has this developing countries. Tourism is the only economic sector to developing countries consistently run a trade surplus. "It's where significant in poorer countries that have few other options for especially 49 so-called least developed countries, tourism is the second world's source of foreign exchange after oil. Revenues from toursecond largest especially important in the developing world, which standsism have been economic losses from any slowdown in tourism. (The to suffer severe Game, 2000).

But the problem with tourism is that it is not an independent industry that cannot be easily affected by other factors. Thus it is dangerous to depend solely on it as a main source of national income. It is directly affected positively and negatively by the armed military operations in the region; in other words, the tourist flow increases with the decrease of such operations and decreases with their increase and intensity. The tragic events of 11 September for instance have shattered the global tourism international tourism continued to following the terrorist attacks. While levels, international travel in 2001 declined by 0 , reaching unprecedented negative growth

(Adam\& Sinclair, M. Thea 2002)

armed Given that the Middle East is the scene for the most influential reconflicts in the world, whether locally or internationally, we can recognize the great extent to which the economy of the Middle East countries could be affected by the decline of the tourist movement resulting from armed conflicts. In fact, the current decrease of the international tourist demand on the Middle East is a result of the violence caused by the regional armed conflicts there, and also by the worldwide security conditions. The Middle East has been one of the most affected regions following the 11/9 terrorist attacks on Washington and New York (Andersen, Arthur 2000).

According to WTO statistics, travel to the Middle East dropped by 8.8 per cent in 2001, compared with 2000 . The same applies to the period of the invasion of Iraq. In short, the insecure conditions in the region have made future prospects for regional tourism vague and uncertain. "If Iraq is attacked, all of us have to forget about tourism for a while," said Nabila Samak, director of public relations at the Semiramis Intercontinental hotel just before the invasion. Instability in the Middle East has meant no tourism. Uniess we have peace and stability in the region, we will not be able to regain our position as a tourist destination (Al-Ahram Weekly $2 / 10 /$ 2002 ).

Instability in the region would be devastating to its economy and tourism industry. The negative impacts of this contraction of the tourist demand on the Middle East on other facilities such as education, health 
services and the infrastruclure are very serious. Armed conflicts are attributed to political decay, facilitate state collapse, cause widespread human rights violations, generate refugees and internally displaced persons, and exacerbate famine conditions. Conflicts also diver scarce resources away from social services, disrupt trade, discourage tourism and contribute to the breakdown of family structures. The pervasiveness and persistence of conflict have also grave psychological consequences as children are traumatized or become accustomed to a culture of vidence (Khalaf-Hunaidi, Rima 1999 ).

On the other hand tourism could bring about the seeds of peace, as the start of tourism developments marks the initial contact between the host and guest. During this stage, few but significant changes take place at the three levels of interactions. (Wahab, Salah 1998).

Firstly tourism begins at a governmental level because government regulations and policies are required to facilitate travel For exampie: Family travel between Lahore and Delhi and between the two sides of the Kashmir area is now possible with the introduction of bus services on these routes. Not only has tourism improved family relations, but also paved way for thawing relations between the two countries. Indeed. tourism often creates a platform for governments to work together towards bilateral agreements such as air rights and visa rules. Tourism may even act as a preliminary communication channel between politically divided countries (Chinchinian, Harry 2002).

This may apply to the Middle East but unfortunately, the Middle East continues to have the greatest number of armed conflicts around the world. Latent or open hostilities resuiting from national and poittical conflicts or religious discrepancy affect most countries in the region. We have the Israel-Palestinian conflict, the US-led war on Iraq, the confrontations between Lebanon's Hizbullah and the Israeli forces, Syria and its conflict with !srae! and the US, the problems in Afghanistan and the existence of Osama Bin Laden's organization al-Qaida, which causes panic to the world community and thus hinder the tourist and travel movement to the area.

There is militant or political Islam and the Islamist fundamental organizations' conflict with the dominant secular regimes in so many Middle East Muslim countries like Algeria, and Egypt. Islamists weave together the struggle in Palestine, the crisis in Iraq, the question of Kashmir, and of course the struggie of the Mujahadeen in Afghanistan into a kind of 'Islamic internationalism' based on the idea of armed confrontation with the forces of imperialism (Andersen, Arthur 2000).

Turkey has also suffered from this at the hands of terrorists over the past 15 years. In fact, Turkey has lost more than 40,000 of its citizens to the Kurdistan Workers Party (PKK) and other terrorist groups. There is also the undercurrent rejection of the US interference with the internal conditions of the area, which lead sometimes to a series of devastating bomb attacks, like the huge truck bomb at the Khobar Towers base near Dhahran, targeting US military and civilian personnel. Important figures from the religious opposition gave a fatwa, or religious judgment, 
excommunicating the Saudi royal family from Islam for supporting the US onslaught on Afghanistan. The demand for US withdrawal from Saud Arabia is a key element of Osama Bin Laden's campaign against the Saudi royal family (The Middle East Forum May 2002)

Terrorism can be regarded as a kind of armed conflict where the terrorists express their conflict with the predominant culture and thought using arms. There is no factor that can lead more to the decline of tourism than terrorism. There have been instances in specific countries where an adverse event affecting tourism has brought about a negative multiplier effect on the nation's economy. There are certain countries like Egypt that are more vulnerable to the adverse economic effects of terrorism on tourism, because tourism is such a significant part of their overall economic activity. Others are less vulnerable to the ill effects of terrorism on tourism, because their economies are more diverse. UAE is a good example (Andersen, Arthur 2000).

Egypt was badly affected by the tragic terrorist events in the 1990s of the last century when many people were assassinated just for being tourists, which was a terrible blow to tourism. On November $1 \bar{\tau}, 1997$, a terrorist attack targeting visitors to the Temple of Hlatshepsut in Luxor, threw Egypt's tourism industry into turmoil. The negative impact of the Luxor tragedy is clearly reflected by the data. The effect of the Luxor tragedy is clearly reflected in the level of visitor arrivals to Egypt in 1998, which declined by 13.8 percent over 1997. International tourism receipts also reflect the impact of the tragedy, with a decrease of 45.4 percent over 1997. Visitor arrivals to Egypt declined by 13.8 per cent from 1997 to 1998. Egypt's international tourism receipts decrease $\mathrm{d}$ by 45.4 per cent in 1998 compared to 1997. Egypt is one of those countries which tourism is a substantial share of overall economic activity (Andersen, Arthur 2000).

That's why the ordinary Egyptians unanimously opposed to a war on Iraq, but not based on rank anti-Americanism. For them it comes down to the economy. In countries where oil and other industries are largely state-owned, tourism is a time-honored source of revenue for the average Middle Easterner.

Tourism is Egypt's second largest foreign exchange earner, and Egypt accounts for 50 per cent of all tourist arrivals coming to Africa and the Middle East. By mid-1997, Egypt seemed well on its way to attracting an expected four million tourists, the highest level for this popular North African destination. But it has lost such advantage after the terrorist attacks. The attack aimed at destabilizing Egypt's tourism industry by striking at a major tourist attraction at the start of the winter peak season, also came at the start of World Travel Market in London, one of the travel and tourism industry's largest trade fairs, at which Egypt was a major participant. Three years later tourism in Egypt is bouncing back. In 1999, tourism growth in Africa and the Middle East outpaced the world average, increasing by 17.5 percent over 1998. (The Global Economics Game, 2000)

Well reported damage control implemented by the Egyptian authorities immediately following the Luxor attack, included increased security 
Journal Of Association of Arab Universities For Tourism and Hospitality, JAAUTH,2006 Votume 2, N0.2

at all tourist sites and hotels, has gone a long way to allay safety fears and restore consumer confidence in the destination. This is clearly reflected in the increase in tours (The Global Economics Game in 1999, which surpassed 1997 levels (The Global Economics Game 2000).

Recognizing the importance of tourism and how it's greatly badly affected by tourism, soon after the mournful drama of September 11, the WTO issued a "Report of the Secretary-General: Terrorist Attacks in the United States of America." The proclamation acknowledged that the "unprecedented and brutal act of terrorism is likely to have profoundly negative consequences for domestic and international tourism." It strongly condemned "heinous acts of terrorism," characterized terrorism as "an enemy of peace and tourism," expressed compassion to the people of the United States and victims of the tragic event, and proffered a firm conviction that "tourism is a resilient sector which has repeatedly demonstrated its ability to overcome problems and weather crises." (WTO. 2001).

\section{Chapter II}

\section{Utilizing International Tourism in stopping the Armed Conflicts in the Middle East}

While tourism is negatively affected by armed conflicts, international tourism can be used as an anti-factor against the eruption of armed conflicts. There are different aspects through which tourism can contribute to the solving of this problem. The economic decline resulting from the slowdown in the tourist movement urges the governments to fight the reasons for this slowdown and slump in the woridwide tourism industry, and save security and peace in the area. In this respect, security has become a significant factor of any propaganda for tourist programs ( $\mathrm{Var}$ , Turgut and Ap John 1998 ).

We can say that the recent terrorist attack, and the possibility of new attacks, has given the travel and tourism a major wake-up call concerning security. In the old travel industry paradigm, industry leaders rarely spoke about threats to tourists in public fearing that such openness would scare away visitors. The common belief was that security was a "necessary evil" that one had to have, but that security added nothing to the business' bottom line. For this reason, tourism and travel security were rarely publicized, never mentioned in marketing campaigns, under-funded, and its practitioners were often underpaid. The old paradigm led to poor security at airports, hotels, restaurants and attractions. Security professionals who spoke of acts of terrorism, bio-chemical attacks, and crime were seen as alarmist and asked to rephrase their warnings in ways that would be acceptable for public consumption (Ramadan, Akmal 2001).

Because of the increase of armed conflicts and terrorism in the host countries, the public was beginning to change its views. Even prior to the September attacks, there were multiple signs that the public began to be 
concerned about and demanded good tourism security. Throughout the travel and tourism industry evidence began to appear that the customers were choosing locations and venues precisely because they were safe and secure. Studies and scholarly articles noted that security personne were beginning to obtain some of the tourism security training that was needed.

The new paradigm for the travel and tourism industry is based on the fact that tourism security is now a major part of a location's marketing strategy, the tourism and travel industry is beginning to assimilate this paradigm change. Tourist companies and airlines have incorporated into their marketing plans the idea that visitor security is their number one priority. State and national tourism conferences are adding speeches about tourism security and its impact on marketing (Ramadan, Akmal 2001).

Tourist Company now should adapt to this paradigm shift. They should recognize that there is a fundamental paradigm, shift in the travel industry. Old assumptions will no longer hold. From a business perspective these old assumptions are very dangerous. Those parts of the travel and tourism industry that emphasize security will have a good chance of surviving. The venues that provide giving good security mixed with good customer service will flourish. Those parts of the travel and tourism industry that hold on to the old way of thinking will fade away (Santana , Gui 2001).

But we should not create a false sense of security. We should deal with the reasons, not the symptoms and ramifications of terrorism and armed conflicts, through gas masks and sealed rooms and the like, or assuring people the police forces will be very alert to any attack. We should instead fight the reasons, which lead to these attacks. The industry workers should know what is unsafe in their community and work with local governments to improve these security concerns. They ought to work hard to restore confidence in the minds of potential travelers regarding airline saf́ety and convenience. If the giobal coaiition of countries combating terrorism is successful at rounding up terrorists, destroying their networks, and confiscating their finances, perhaps confidence will be restored and international travel will return to some semblance of normalcy (Santana, Gui 2001).

In attempting to resolve the problems, which lead to conflict and terrorism in the Middle East, we should look to the internal conditions of the Middle East countries. The approaches like "hostile countries", "foreign troops", which are mentioned frequently in Middle East countries can be misleading, even if they have some bases in reality. If there is a terror existing widespread somewhere, it is necessary to admit and determine that there is something going wrong. Terrorists come from our people, target our people, and act inside our borders. Accordingly, the solution should be sought on the same soil, but this does not mean that one should ignore the impact of foreign troops (Ramadan, Akmal 2006)

Among the reasons, which lead to terrorism and armed conflicts in the Middle East, are the people's poor economic conditions Economic 
pressures have corroded the Arab rulers' domestic support to the 2 , No.2 where it is hard to see any of the current regimes regaining the level of popular legitimacy they enjoyed a generation ago. In Egypt, for instance living standards have been falling for more than a generation. The calaries has not slackened for the last aries has fallen on a regular basis. In addition the public health and education systems are approaching collapse after years of degradation. Thus the only way to pass crucial high school and university exams is by paying for the expensive private tutorials, which teachers offer to increase their meager salaries. The conditions are not much better in most Arab countries. This will make the people lose confidence in the ruling regimes, which sometimes resort to a brutal security apparatus to stifle dissent (Ramadan, Akmal 2006).

What make people much more displeased and leads to armed conflicts and terrorism are the political, economic, and cultural imperialism the US imposes on the Middle East countries. Most Middle East countries now regard America as a "big brother" to whom they turn for guidance and support and for whom they can express nothing but absolute obedience and respect.

In fact, imperialism intensifies the impact of economic crisis around the Middle East by creating conditions in which anger over economic issues can quickly spill over into a more generalized challenge to the regime as a whole. Internal economic crisis and external intervention are the subjective conditions, which are ultimately crucial in turning riots into organized demonstrations, and street clashes with the police into a mass movement. The issue of Palestine and the Intifada are a key marker for this process of radicalism. Demonstrations done by students in Egypt at the outbreak of the uprising were quickly joined by workers. Slogans on the protests moved on from demands for dismissing the Israeli ambassador to the issues of high prices, corruption of government and state oppression. Across the Middle East in general, the connection between local economic crisis and the imperialist intervention could bring about further serious confrontations between the local and global ruling classes and the peoples of the region (Santana, Gui 2001).

As I have already mentioned protecting the tourism industry could be a very significant motive prompting the Middle East leaders to correct the mistakes of their regimes and consequently avoid the reasons of terrorism and internal and external armed conflicts. Now there is no doubt that the weakening of social order is an important factor that would bring about a potential disorder, which is the result of terror. The healthier a body is the more resistant and immune against viruses. Measures have to be taken to make the region more democratic in order to put an end to terrorism (Mowforth, Martin, Munt, lan 2004).

The Middle East governments should respect the rule of law, human rights, and freedom of expression. Of course the most important weapon against terrorism is education. We should regain the hearts and minds of our children back from extremists through education. The power of democracy and our way of life depend on the future generations of educated boys and 
girls who respect knowledge, moderation, education, and gender equality Consequently, the terrorist activities resulting from the socio-econolity conditions of the society and the failing of the existing system will have no soil to grow in. Terrorism will live as long as the imbalanice an displeased people (Zahran,Ahmed S \& Ramadan, Akmal 2006 ). Many

In any attempt to stop armed conflicts in the Middle Eas can not ignore the urgent need to make the Middle East, we from the WMDs in order to attract the international investments in free and tourist investments in particular. We need also to fight genera transfer of the light weapons. The Middle East is an attractive market for opportunistic arms merchants. In fact, arms transfers and trafficking remain one of the Middie East major security problems. The influx of light weapons has prolonged the conflicts in the Middle East and made them more dangerous. The international community's inability to control arms transfers and trafficking contributes in the persistence of these devastating
conflicts (Santana, Gui 2001).

There should be international and regional efforts to control arms transfers and trafficking. Arms transfers and trafficking have continued to spiral, in part, because the international community has not effectively enforced UN sanctions or criminalized siege violations or penalized financial institutions that act as agents for weapons purchases and also failed to promote local controls over arms production and sales to countries under UN arms embargoes, or taking actions against countries that serve as arms transshipment points (Nazarkin, Yuri K 1998).

There should be international and regional programs to reduce the flow of weapons coming to the Middle East. There should be genuine initiatives to stop the devastating impact that arms transfers have on the Middle East. The United Nations in particular has to exert its greatest effort to enforce its arms embargo against any country that violates its resolutions.

Beyond arms embargoes, the UN and some member states, notably Canada and Great Britain, have advocated a "name and shame" policy. According to UN Secretary General Kofi Annan, the "public identification of international arms merchants" is the single most important tool in combating the arms trafficking problem. On September 24, 1999, the UN Security Council held its first ministerial meeting on small arms; this led to a Security Council presidential statement urging member states to curb arms trafficking. The UN's "name and shame" strategy has had no impact on weapons flows. To ameliorate the arms trafficking problem in the Middle East, the international community should be willing to levy painful individuals or countries to dissuade them from selling arms to or within the Middle East (Resolution 59/74 adopted by the General Assembly 2004).

The ultimate vision of tourism is to attain peace through fostering amiable host-guest relationships founded on shared cultural understanding and acceptance and equitable returns. At this stage, the world enjoys political, economic, environmental, and socio-cultural 
journal ${ }^{\mathrm{n}}$ Association of Arab I/niversities For Tourism and Hospitality. JAAUTH, 2006 Volume 2, No.2 stability. Because we are within the geographical boundaries of issues are no longer restricted wer towards maintaining world peace a place. Every 1998 ).

Last year, when the Indian Ocean earthquake and tsunami hit Asia, travel almost came to a standstill in the affected destinations. The impacts of sluggish tourism performance, whe travel industry and prompled wown the economy highlighted the value cooperate in restoring peace and organizations and govere among people (Xiangru Tang, Clara 2005) regaining travel

Tourism in itself can be an important factor that contributes in getting rid of some of the major causes of terrorism and armed conflicts. No one can deny the role of the tourist investments in solving unemployment problems and other social ones, which result in violence and terrorism. There is also a role which international tourism can play in achieving constructive communication and closeness between different peoples from different cultural background. (Wahab, Salah 1998 ).

Most international and local conflicts result from not respecting the other's ideology.. The terrorists' attack on tourism in the Middle East is mostly grounded in the idea that tourism forms a threat to the cultural and religious heritage of their conservative countries and may lead to adverse impacts on their lifestyles. According to them, visitors who show little respeci for the sanctity of spiritual places, practices and traditions by conducting themselves in a rash manner can have an adverse impact on those places and the communities that regard them as important parts of their cultural identity. (Voicu, loan 2004).

But this view reflects a narrow understanding and a lack of insight into the underlying theory of tourism. "Tourism must not have such negative impacts," Mastny says. "Many governments and businesses, local communities, and tourists themselves are already paying more attention to the social, cultural, and environmental impacts of their activities." (Masiny , Lisa, 2001).

It can be planed to facilitate and encourage the tourism industry to promote and manage tourism in ways that respect and enhance the heritage and living cultures of the host communities, and to facilitate and encourage a dialogue between conservation interests and the tourism industry about the importance and fragile nature of heritage places. collections and living cultures including the need to achieve a sustainable future for them (Voicu, loan 2004).

In fact, there is an active relation between tourism and mutual understanding between the nations. Domestic and international tourism continues to be among the leading vehicles of cultural exchange. It provides a personal experience, not only that which has survived from the past, but also the contemporary life and society of others. It is increasingly appreciated as a positive force for natural and cultural conservation. Tourism can attract the economic distinctiveness of heritage and harness these for conservation by gererating funding, educating the community and influencing the ongoing policy. It is an essential part of many national 
and regional economies and can be an important factor of development, when managed successfully (Wahab , Salah 1998).

Tourism itself has become an increasingly complex phenomenon, with political, economic social, cultural, educational, biophysical, ecological and aesthetic dimensions. Natural and cultural heritage, diversities and living cultures are major tourism attractions. The achievement of a beneficial interaction between the potentially conflicting expectations and aspirations of visitors and the host or local communities presents many challenges and opportunities. (Mastny, Lisa, 2001).

The tourist does not want the same culture of his homeland but he seeks cultural difference. He leaves the familiar place of home and travels to a foreign and strange place in order to experience the difference between here and there. This cultural difference is material, historical, religious, political, economic, and social one. The reason for this search for something different is that the imagination of the capitalist "first world" is exhausted. It cannot imagine anything different, so the tourist leaves the homogenous space of "home" for the heterogeneous space of "foreign climesn simply to admire the picturesque, the mere view or snapshot of difference, to see the difference. This cultural difference is rooted in language, landscape, architecture, custom, taste, and smell. It is very physical. The more it is used up or taken away, the less remains, and thus the less it will be attractive to tourists (Bey, Hakim 2000).

Those conservative people who are against tourism coming to the Middle East, particularly to the Muslim nations and believe that it will put it in danger of extinction of their native culture and cultural heritage, should be convinced that tourism could bring many benefits to the host communities and provide an important means and motivation for them to care for and maintain their heritage and cultural practices(Tantawy, Mohamed S2005).

They should be aware of the fact that the tourist seeks out culture and difference. The involvement and cooperation of loca! or indigenous community representatives, conservatives, tourist operators, property owners, policy makers, those preparing national development plans and site managers are necessary to achieve a sustainable tourism industry and to enhance the protection of heritage resources for future generations

\section{Conclusion:}

Due to the intricacies of personal and political interactions, tourism is only one of the vehicies for building peace because issues such as religious and political beliefs are also central in shaping relationships. I argue that the world's largest industry (Tourism) is looked upon as a central force for advocating peace. The tourism industry is certainly a significant step in bridging people together and creating universal peace.

i have attempted by way of this research to shed much light in the role which tourism may play in solving the armed and political conflicts in the Middie East, and consequently it will have a position impact on the courntres of that region including Egypt, considering tourism as a tool of 
journsl Of Association of Arab Universities For Tourism and Hospitality, JAAUTH,2006 Volume 2, No.2
the peace and acquaintance among peoples. And this is what has been include the Manila declaration of world tourism in 1980 issued from Manila tourist conference the presence of the representatives of these states which established a basic principle that the world tourism must have the ability to be an affective power to achieve world peace. This declaration has been made sure of by Colombia declaration issued from the conference which titled "tourism is a push toward peace" held in Frankfort in the united states in October 1998 which issued the creed o the peaceful traveler (Wahab, Salah 1998.)

In the above-mentioned research, we have presented the role of tourism as a means for civilization dialogue instead of the clashes of civilization is considered as the first affected sector by wars, violence and terrorism in the world generally and in the Middle East particularly. Egypt may be one of the countries that have been affected by some negative impacts of the tourism sector as a result of the contentious situation of the Middle East. The thing that calls tourism to defend itself and its legitimate existence, and surely the best way is by playing a role in solving the military and political disputes in the Middle East (Andersen, Arther 2000).

Then tourism through its ability in the economic and social development, could plant better concepts for dialogue between different governments in many aspects as concluding agreements of air transport, granting aviation liberties, granting vises, avoiding double taxation and customs. In addition to the relationships between businessmen who have deferent nationalities in tourism development and hotel construction domains, do undoubtedly contribute in establishing the bonds and ties of dialogue and contact. Add to that, the economic importance of tourism pushes the governments to think seriously in solving the political disputes peacefully and to leave no stone unturned before resorting to the political and military escalation, which is considered as a repellent factor of tourism that has many negative impacts (Robinsson, $M \&$ Bonifak \&p 1998)

In the end, I would like to give some brief space to my suggestions concerning how to benefit much from world tourism as a significant means of solving armed conflicts. On top of these suggestions is providing easy and safe travel ways for the tourists from their countries to the neighboring countries to get acquainted with new civilizations, cultures, life styles and ways of thinking; improving the curricula in the Middle East countries in a way that includes encouraging peace and international dialogue, and purifying these curricula from whatever thoughts and ideologies that stimulate violence and fundamentalism. There is also a great need for activating the role of the international, social and religious arganizations in urging a constant and influential dialogue between different civilizations, adopting the idea of accepting the other, whosoever this other can be, and encouraging peaceful co-existence instead of the aggressive idea of armed confrontations. All this can be done through the local governments of the Midale East under the auspices of the international organizations, particularly the United Nations. 

In the end, I would like to give some brief space to my suggestions
concerning how to benefit much from world tourism as a significant means
of solving armed conflicts. On top of these suggestions is providing easy
and safe travel ways for the tourists from their countries to the neighboring
countries to get acquainted with new civilizations, cultures, life countries to get acquainted with new civizations, cultures, life styles and ways of thinking; improving the curricula in the Middle East countries in a way that includes encouraging peace and international dialogue, and purifying these curricula from whatever thoughts and ideologies that stimulate violence and fundamentalism.

There is also a great need for activating the role of the international, socia and religious organizations in urging a constant and influential dialogue between different civilizations, adopting the idea of accepting the other whosoever this other can be, and encouraging peaceful co-existence instead of the aggressive idea of armed confrontations.

All this can be done through the local governments of the Middle East under the auspices of the international organizations, particularly the United Nations. 

Journal Of Association of Arab Universities For Tourism and Hospitality, JAAUTH,2006Volume 2, Na.2
References:

Al-Ahram Weekly 2/10/2002: At: weekly ahram org.eg/2002/605/ec3. htm Arthur Andersen (2001): Tourism and Terrorism - The Road to online.com/Trends/Anderse

Bey, Hakim(2003): Overcoming Tourism, Neoscenes Net, A bridge between eye and soul. An essay available online At http://neoscenes.net/hyper-text/text/hird/tourism.html

Blake,Adam\& Sinclair, M. Thea (2002) : Tourism Crises Management Responding to September 11, Christel DeHaan Tourism and Travel Research Institute Nottingham University Business School ., Available at http://wnw. nottingham.ac. uk/ttri/pdf/2002 7.PDF

Clara Xiangru Tang(2005): Building A Culture of Peace through Tourism, School of Travel Industry Management , University of Hawaii, at Manoa. At: http://www.iipt.org/3rdglobalsummit/ essaybuilding a culture of peace.htm

Frangialli ,Francesco (2003): At the meeting of the United Nations Economic and Social Council (ECOSOC)., (Geneva, 10 July 2003)

Harry Chinchinian (2002) India Pakistan in War and Peace - Routledge (UK) P. $268-268$

IIPT Global Conferences (2004): The institute of international Peace through Tourism Available at: http://www.iipt.org

loan ,Voicu (2004): Tourism, as a means of bringing people closer together, is a force for harmony and peace between nations, cultures, religions and individuals, at http://www.worldtourism.org/tsunami/news/64.pdf

Khalaf-Hunaidi, Rima, (1999): Peace in the Middle East and the Jordanian Economy., Featuring; At: http://www. Washington

institute org/templateC07.php?CID =33

Martin Mowforth, Ian Munt ( 2004 ) : Tourism and Sustainability: Development and New Tourism in the Third World., p. 275.

Mastny, Lisa (2001) : Tourism, Terrorism, and Tomorrow, World watch Institute-December 13, 2001, available At: http://www. Worldwatch.org/node/1713

Nazarkin , Yuri K (1998): Arms Control and Disarmament, $1^{\text {st }}$ Conference of the PfP Consortium of Defense Academies and Security Studies Institutes "Networking the Security Community in the Information Age"19 - 21 October 1998, Kongresshaus Zurich, Switzerland, Online Publications available at : http://www.isn. ethz.ch/3isf/Online Publications/WS5/WS 5D/Nazarkin1.htm

Mandela, Nelson (2000): At the Global Summit on Peace Through Tourism in Amman, Jordan, November 8-11, 2000 http://wnw. africaata.org/peace.htm 
President Sadat's Address to the Knesset, November 20, 1977. http://mww. alsadat2.4t.com/SPEECHES/president sadat.htm

Ramadan, Akmal

(2001): The obligation of safety in tourism contracts, The Legal and Economic magazine of the faculty of Law at Zagazig University.

(2006): The Egyptian tourism between the international politics and the universal culture, Think Tank VI, Spain, 2006.

Resolution 59/74 adopted by the General Assembly (2004): Assistance to States for curbing the illicit traffic in small arms and collecting them available online at: http://umw.iansa.org/un/ bms2005/N0448070.pdf

Santana , Gui (2001) : Globalization ,National security in Tourism in the age of globalization edited by Salah Wahab and Chris Cooper, Routledge P. 213-219.

Tantawy, Mohamed S (2005) : An oral presentation to the Conference of the Tourism from an Islamic view, March, 2005, Saleh Kamel center of The Islamic Economy, Alazhr Uni, Egypt.

The Global Economics Game (C) (2000): Terrorism Vs Tourism At: http:www.worldgameofeconomics.com/TerrorismVsTourism.html

The Middle East Forum: May 31, 2002 At http://www.meforum.org/article/299

Turgut Var and John Ap (1998): Tourism and world Peace in William F Theobald ., Global Tourism: The Next Decade., p. 45-48

Wahab, Salah:

(1996): Tourism in a variable world, Cairo unpublished, 1996 p.217.

(1998): Tourism a factor for peace and tolerance, the annual book of tourism and hotel, Dar El Maaref, p.25-29.

(2003): the Egyptian tourism in the age of globalization, south call magazine, issued from the center of the development nation researches and studies p.47.

World Tourism Organization (2002): Tourism and Poverty Alleviation WTO, Madrid http://www. worldtourism. org/isroot/wto/pdf/1267-1.pdf

Zahran,Ahmed S \& Ramadan ,Akmal ( 2006 ): Egyptian tourism education between the quantity and the quality. An Oral presentation to the Conference of the Tourism Education Development in Egypt, March, 2006, Al-Fayoum faculty of tourism and hotel management. 
Journal Of Association of Arab Universities For Tourism and Hospitality, JAAUTH,2006Volume 2, $\mathrm{N}_{0.2}$

Tourism as a means of resolving the armed conflicts in the Middle East

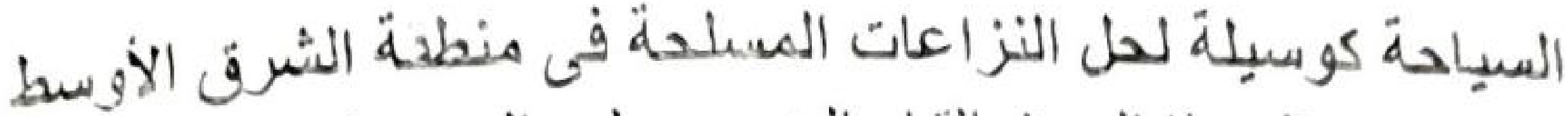

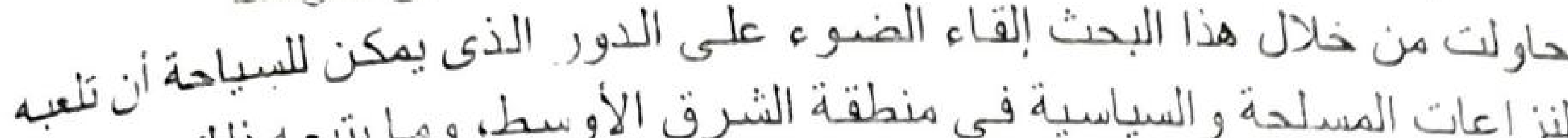

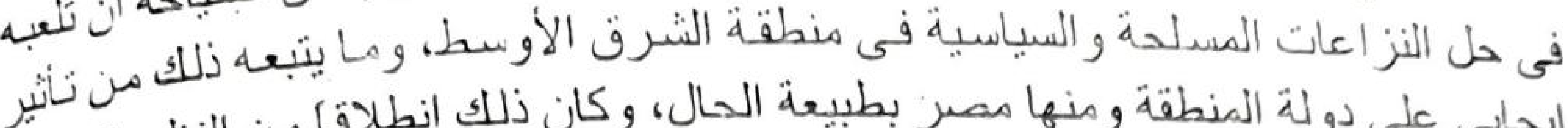

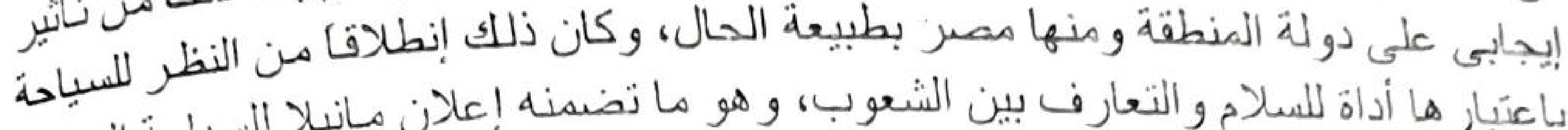

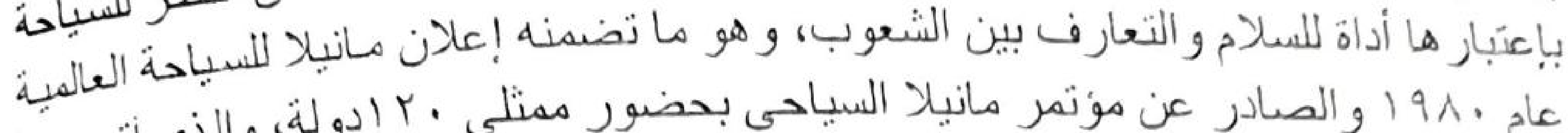

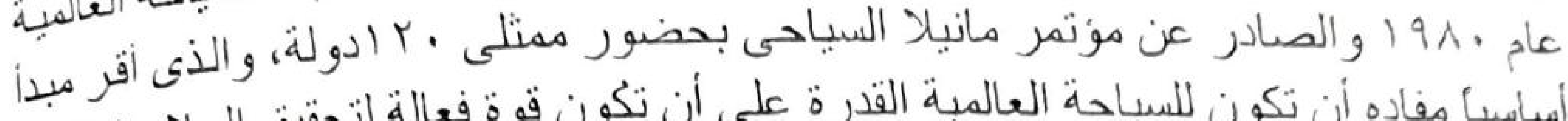

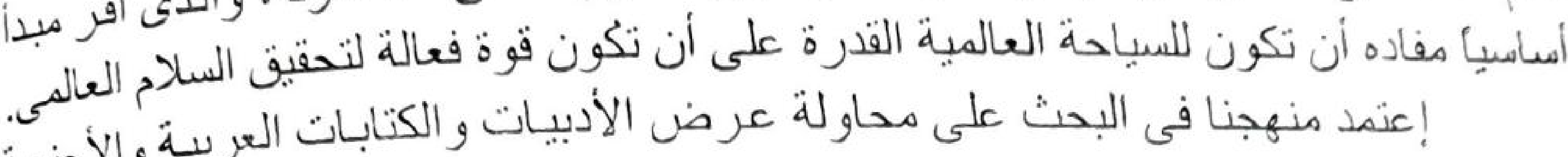

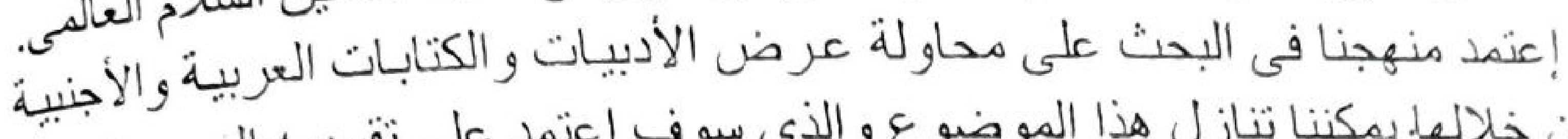

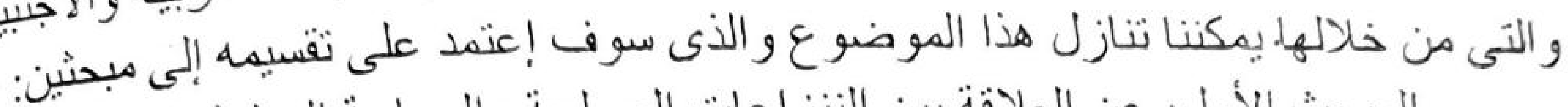

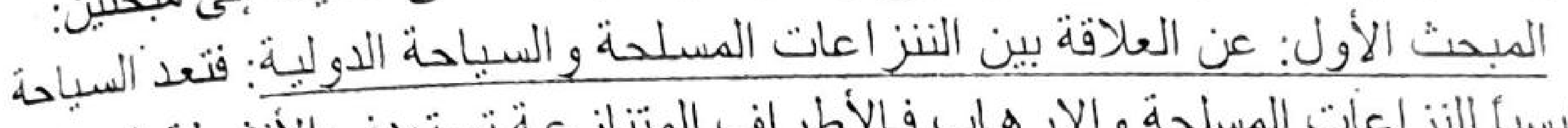

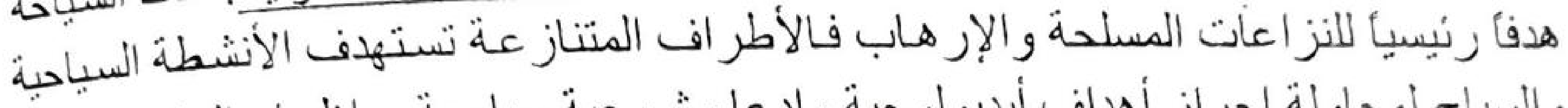

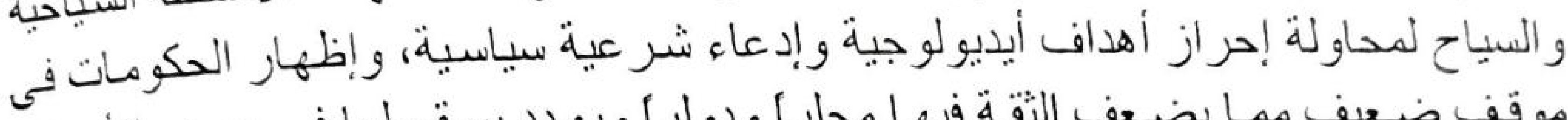

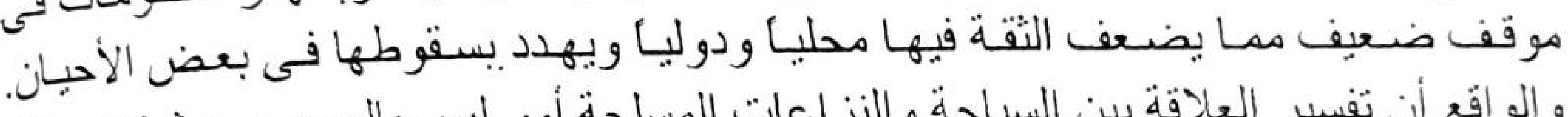

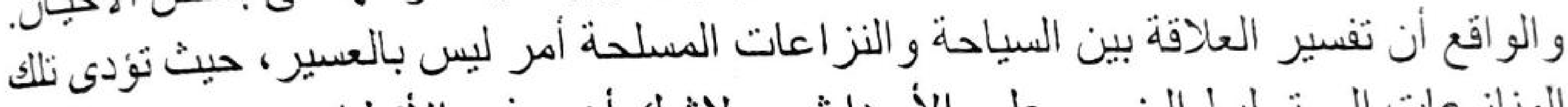

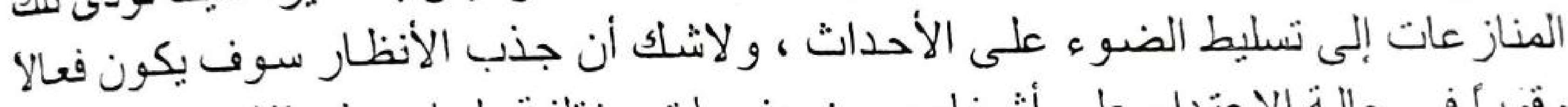

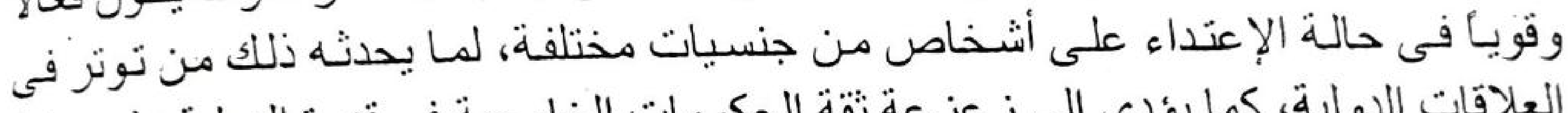

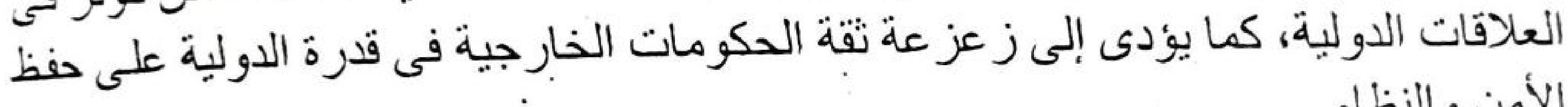

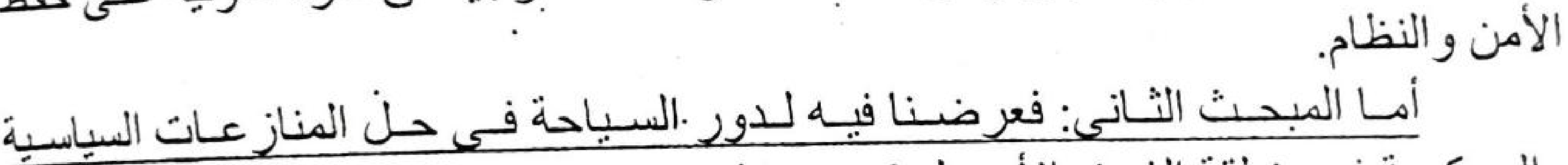

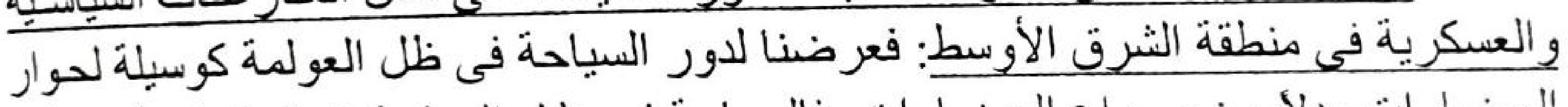

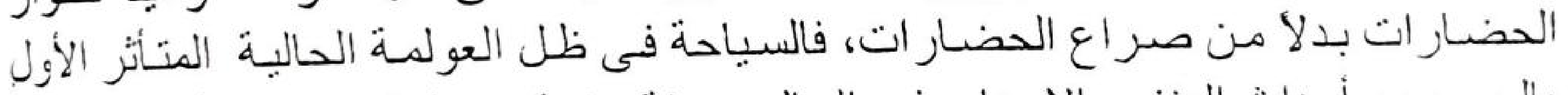

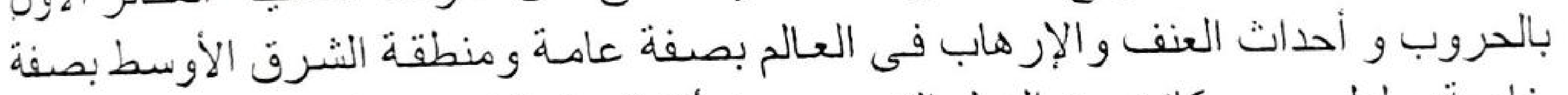

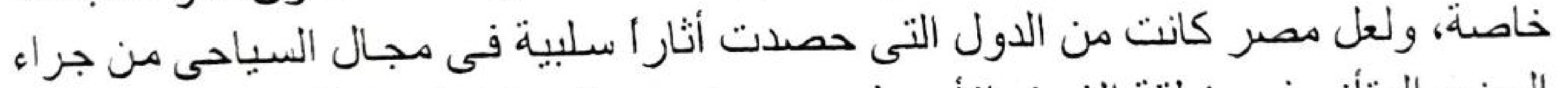

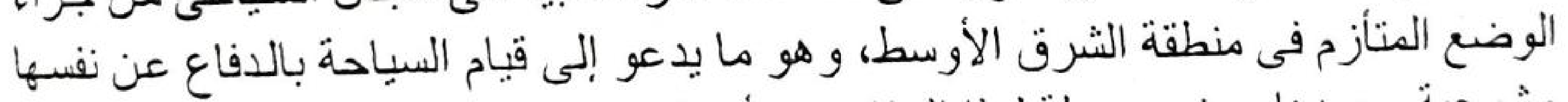

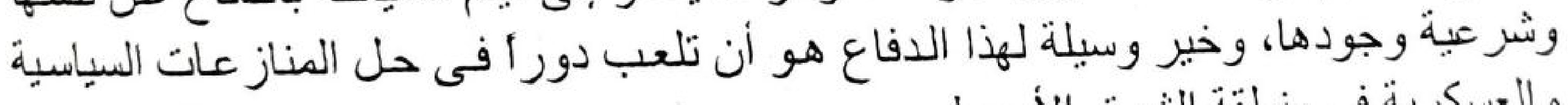
و العسكرية فى منطقة الشرق وخئ الأوسط.

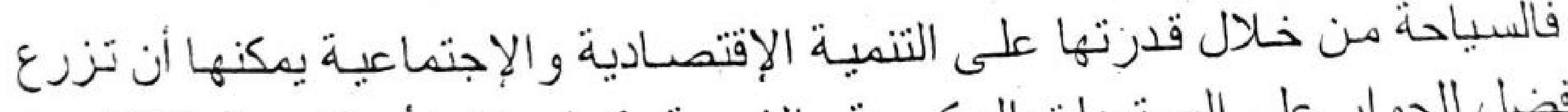

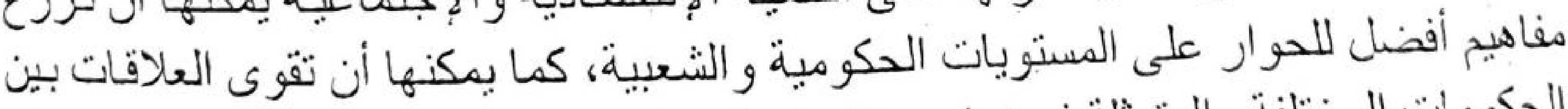

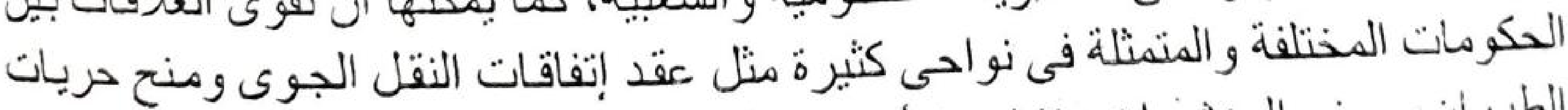

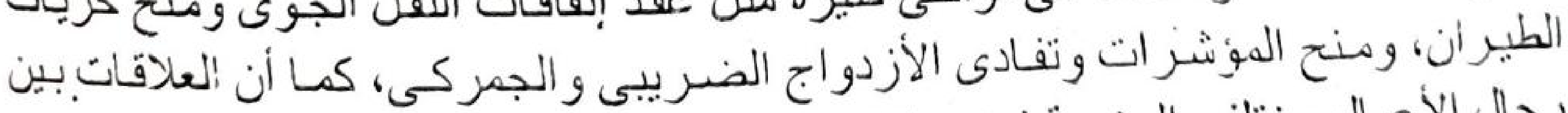

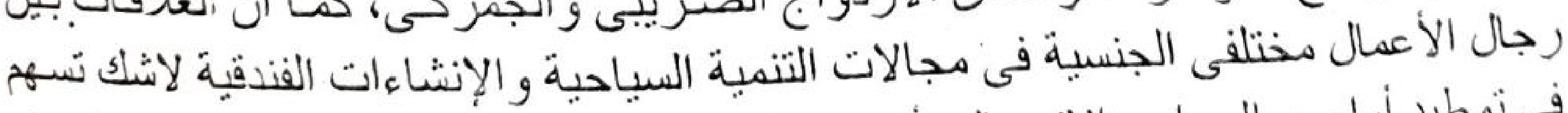

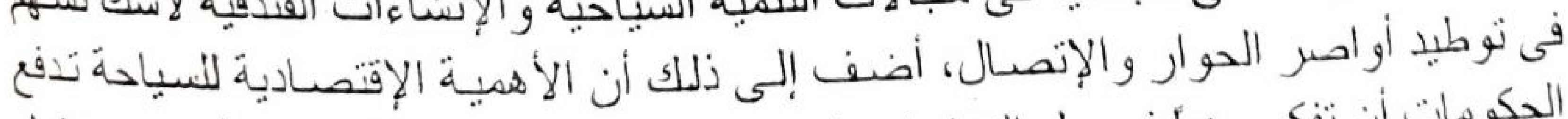

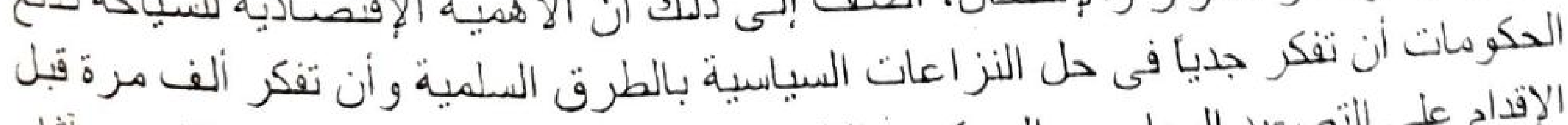

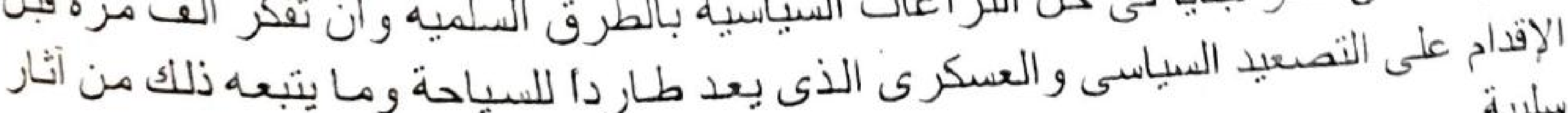
سلبية القان ثُ عرضنا لأهم النتانج و النوصبات المقتر حة. 